\title{
Aquatic Macrophytes Detritus Quality and Sulfate Availability Shape the Methane Production Pattern in a Dystrophic Coastal Lagoon
}

\author{
André Luiz dos Santos Fonseca ${ }^{1 *}$, Claudio Cardoso Marinhoo ${ }^{2}$, Francisco de Assis Esteves ${ }^{3}$ \\ ${ }^{1}$ Instituto Federal de Educação, Ciência e Tecnologia do Rio de Janeiro, Rua Carlos Wenceslau, Rio de Janeiro, \\ Brasil \\ ${ }^{2}$ Laboratório de Limnologia, Departamento de Biologia, Universidade Federal do Rio de Janeiro, Rio de Janeiro, \\ Brasil \\ ${ }^{3}$ NUPEM-Universidade Federal do Rio de Janeiro, Macaé, Brasil \\ Email: ${ }^{*}$ andre.fonseca@ifri.edu.br
}

Received 1 May 2015; accepted 27 June 2015; published 30 June 2015

Copyright (C) 2015 by authors and Scientific Research Publishing Inc.

This work is licensed under the Creative Commons Attribution International License (CC BY).

http://creativecommons.org/licenses/by/4.0/

(c) (i) Open Access

\section{Abstract}

Aquatic macrophytes usually show high productivity rate, especially in shallow environments, and may constitute the main source of organic matter to these ecosystems. The coastal lagoons are shallow environments that typically present a broad colonization by aquatic macrophytes. The organic matter derived from aquatic macrophytes consists of detritus and root exudates, from live plants. Methanogens are microorganisms that use labile organic matter (e.g. acetate) in the metabolism, releasing methane $\left(\mathrm{CH}_{4}\right)$ as an end product. Assessing the influence of aquatic macrophytes on methanogenesis is fundamental to understanding the carbon cycle in shallow environments, such as coastal lagoons. A peculiarity of coastal lagoons that may also influence the methanogenesis is its proximity to the sea, providing the entrance of sulfate in the environment. The methanogenesis can be inhibited by the sulfate reduction when there is sulfate availability sulfate. In this context, we aimed to analyze the methane production in an aquatic macrophyte stand and in the limnetic region of a coastal lagoon, assessing the influence of quantity and quality of organic carbon and sulfate availability on methane production in the sediment profile. We observe that the presence of aquatic macrophytes benefits the methanogenesis, not only by detritus accumulation, but particularly by the release of root exudates from the living plants. The variation in quantity and quality of organic carbon is the main factor that controls the range and shape of the methane production curves. The availability of sulfate presents probably a secondary role, being im-

\footnotetext{
${ }^{*}$ Corresponding author.
} 
portant when the organic matter is not sufficient for the occurrence of methanogenesis and sulfate reduction simultaneously.

\title{
Keywords
}

\author{
Methanogenesis, Sediment, Root Exudates, Competition, Shallow Environments
}

\section{Introduction}

Methanogenesis is the primary route of anaerobic decomposition of organic matter in freshwater sediments, accounting for $30 \%-80 \%$ of anaerobic carbon (C) mineralization [1] [2]. In this process, the $\mathrm{C}$ is converted in methane $\left(\mathrm{CH}_{4}\right)$. Methanogenic degradation of organic matter in sediments relies on a syntrophy among a complex microbial community consisting of fermentative and hydrolytic bacteria, acetogens and methanogens, which act in sequence and simultaneously [3] [4]. However, methanogenesis usually is outcompeted in environments in which alternative electron acceptors (such as oxygen, nitrate, ferric iron $\left(\mathrm{Fe}^{3+}\right)$, and sulfate $\left(\mathrm{SO}_{4}^{2-}\right)$ ) are available. Consequently, freshwater sediments are spatially structured in a vertical sequence of microbial zones according to the availability and the disappearance of electron acceptors, and at the end, methanogenesis predominates [5].

Coastal lagoons are unique wetland ecosystems in relation to the process of methanogenesis due to two peculiar characteristics: 1) the broad development of aquatic macrophytes, promoting the accumulation of detrital organic matter and the release of root exudates from these plants. Many studies show that $\mathrm{CH}_{4}$ production is higher in the uppermost sediment layers, which receive fresh carbon inputs from aquatic macrophytes [6] [7], such as coastal lagoon [8] [9], indicating an interaction between aquatic macrophytes and methanogens, through the availability of substrates derived from plants to the microorganisms; 2) the proximity to the sea, providing the entry of seawater sulfate through sea spray or, more drastically, by natural or anthropogenic sandbar openings [10]. Sulfate reduction may diminish the overall potential of $\mathrm{CH}_{4}$ production in coastal lagoons, since sulfate reducing bacteria show higher affinity for substrates common to both types of microorganisms [11]. However, the two processes can occur simultaneously if there is sufficient availability of common substrates [12].

Another important role of coastal lagoons is related to the global warming effect, since wetlands are the main natural source of methane to the atmosphere [13]. Methane produced in sediments along littoral regions of coastal lagoons accounts for most of the bubble flux (ebullition), in function of high methane concentration sediment values, and plant mediated flux to the atmosphere (e.g., [14]-[16]). Considering that methane is 25 times more potent as a greenhouse gas than carbon dioxide [17], understanding the factors that regulate the methane production in the sediments of coastal lagoons has important local and global ramifications. In this study, through an experiment in laboratory microcosms, we aimed to analyze the methane production in a stand of aquatic macrophytes and in the limnetic region of a dystrophic coastal lagoon, assessing the influence of quantity and quality of the organic carbon and of the sulfate availability on the production of methane in the sediment profile.

\section{Materials and Methods}

\subsection{Study Area}

The Comprida lagoon is situated in the coastal area of the Macaé region, Brazil $\left(22^{\circ} 30^{\prime} \mathrm{S}\right.$ and $44^{\circ} 42^{\prime} \mathrm{W}$ ) (Figure 1). This area is localized in the Restinga de Jurubatiba National Park, a mosaic landscape of 14,860 ha composed of shrub vegetations, flooded forest patches and coastal lagoons on the Atlantic coastal plain. The regional climate is warm and humid; temperatures range from $18.7^{\circ} \mathrm{C}$ to $27.4^{\circ} \mathrm{C}$ with lowest precipitation in winter (43.8 $\mathrm{mm})$ and highest in summer $(185.8 \mathrm{~mm})$ [18]. The lagoon is completely separated from the ocean by sand bars about $100 \mathrm{~m}$ in width.

Morphological and limnological parameters are listed in Table 1. Comprida lagoon is a small shallow environment, with area of $0.1 \mathrm{Km}^{2}$, and depth $1.96 \mathrm{~m}$ in limnetic region. In the Comprida Lagoon the water is colored by humic substances, resulting in lower values of transparency and higher values of color (Table 1). 


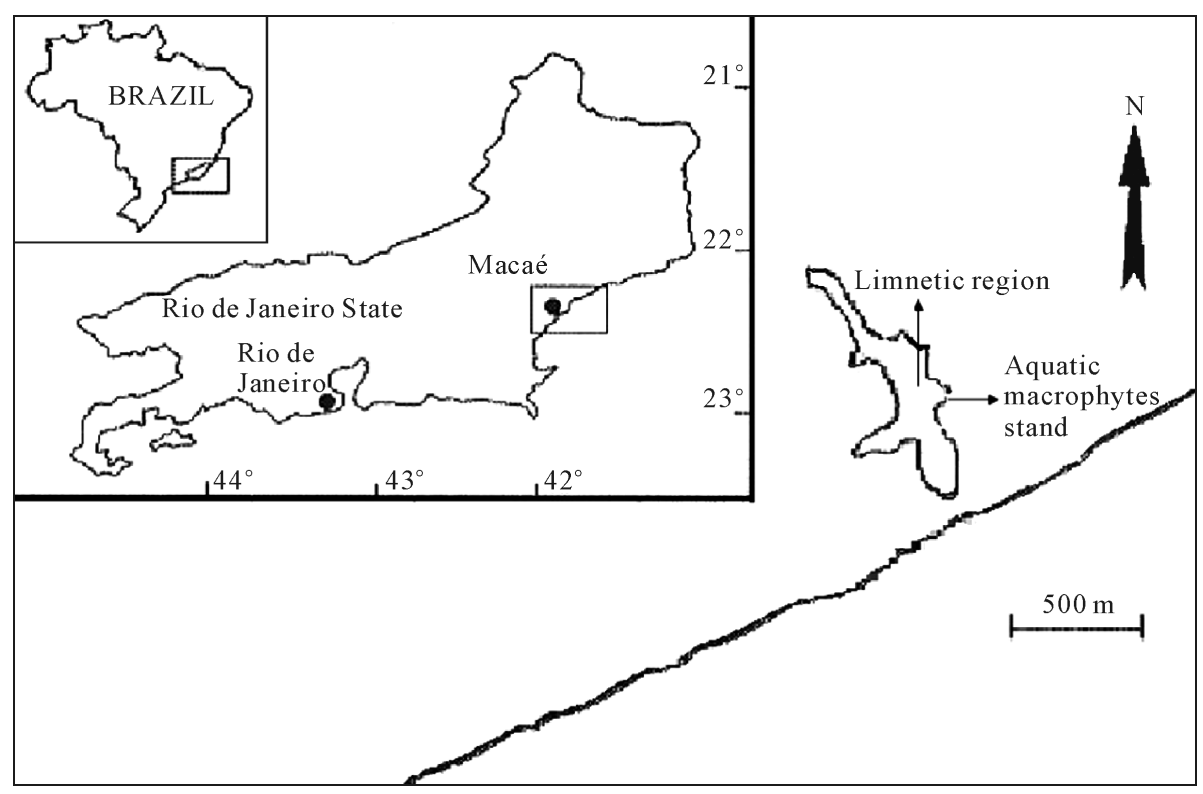

Figure 1. Localization of Comprida Lagoon. The arrows indicate the two sampling stations.

\begin{tabular}{cc}
$\begin{array}{l}\text { Table 1. Morphological and limnological parameters } \\
\text { of Comprida Lagoon. }\end{array}$ & Values \\
\hline Variables & 0.1 \\
\hline Area $\left(\mathrm{Km}^{2}\right)^{1}$ & $1.96 \pm 0.36$ \\
Depth mean $(\mathrm{m})^{2}$ & $0.114 \pm 0.034$ \\
Water color $(\text { Abs } 430 \mathrm{~nm})^{2}$ & $0.5 \pm 0.2$ \\
Secchi depth $(\mathrm{m})^{2}$ & $27.4 \pm 4.6$ \\
Air temperature $\left({ }^{\circ} \mathrm{C}\right)$ & $25 \pm 2.9$ \\
Water temperature $\left({ }^{\circ} \mathrm{C}\right)$ & $5.2 \pm 0.5$ \\
pH ${ }^{2}$ & $0.2 \pm 0.1$ \\
Salinity & \\
Total Nitrogen $(\mu \mathrm{M})^{2}$ & $46.13 \pm 16.85$ \\
Total Phosphorus $(\mu \mathrm{M})^{2}$ & $0.52 \pm 0.31$ \\
DOC $(\mathrm{mM})^{3}$ & $2.36 \pm 0.85$ \\
Oxygen dissolved $\left(\mathrm{mg} \cdot \mathrm{L}^{-1}\right)$ & $6.3 \pm 2.3$
\end{tabular}

\footnotetext{
${ }^{1}$ According to [19]; ${ }^{2}$ Data from January to December 2003; ${ }^{3}$ Data from August to December 2003.
}

Humic substances are rich in nitrogen, and can reduce values of $\mathrm{pH}$.

\subsection{Sampling}

The Sampling was carried out in January 2004 using a core sampler as described in [20]. At each location sediment cores $(\mathrm{n}=5)$ were taken at the limnetic region and aquatic macrophytes stand of E. Interstincta (Vahl) Roem. \& Schult. Immediately after sampling the cores were sent to the laboratory under refrigeration in an ice cooler. Only the upper $10 \mathrm{~cm}$ were considered, and sub-fractionated into three layers $(0-2 \mathrm{~cm}, 2-6 \mathrm{~cm}$ and 6 $10 \mathrm{~cm})$. 


\subsection{Methane Production}

In laboratory, five grams of the sediment collected was transferred to $25 \mathrm{ml}$ flasks, and $5 \mathrm{ml}$ of autoclaved water from the lagoon was added. The flasks $(n=5)$ were closed with rubber stoppers, and the residual $\mathrm{CH}_{4}$ and $\mathrm{O}_{2}$ was removed by flushing with $\mathrm{N}_{2}$ for $2 \mathrm{~min}$, creating an anoxic and $\mathrm{CH}_{4}$ free condition. The flasks were incubated statically in the dark in a constant temperature $\left(25^{\circ} \mathrm{C}\right)$. The $\mathrm{CH}_{4}$ concentration in the headspace was measured by GC analysis (VARIAN Star 3400-Varian Co., USA), with a FID detector temperature of $220^{\circ} \mathrm{C}$, an injector temperature of $120^{\circ} \mathrm{C}$, a $1 \mathrm{~m}$ Poropak-Q column (60/100 mesh) at $85^{\circ} \mathrm{C}$ and $\mathrm{N}_{2}$ as the carrier gas. The concentrations of $\mathrm{CH}_{4}$ in the vial headspace were monitored regularly during 53 days.

\subsection{Methane Concentration}

Sediment samples $(5 \mathrm{~g})$ were placed in $25 \mathrm{~mL}$ glass vials $(\mathrm{n}=5)$, containing $5 \mathrm{~mL}$ of $\mathrm{NaOH}(4 \%)$ to inhibit biological activity and expel the methane from the pore water [21]. The flasks were closed with rubber stoppers and then shaken. The $\mathrm{CH}_{4}$ concentration in the flasks' headspace was measured as described previously earlier in the methane production section.

\subsection{Laboratory Analyzes}

The interstitial water of the sediment was separated by sediment filtration with a vacuum pump. Subsequently, the water was filtered through a $1.2 \mathrm{uM}$ filter (GF/C, Whatman). Dissolved organic carbon (DOC) was determined by subtracting the inorganic carbon (IC) values from the total carbon (TC) values. IC and TC were analyzed with a carbon analyzer (TOC Analyzer 5000, Shimadzu Co., Japan). The soluble carbohydrates concentration was determined according to the phenol-sulfuric acid method by Dubois [22]. The sulfate concentration in the sediment pore water was determined by the formation of barium sulfate [23].

\subsection{Statistical Analyzes}

Methane production (dependent variable) in the sediment of limnetic region and in the stand of aquatic macrophytes (categorical variables) per sample time (continuous variable) was compared using analysis of covariance (ANCOVA; significance level of 0.05). DOC, carbohydrates, $\mathrm{SO}_{4}^{2-}$ and $\mathrm{CH}_{4}$ concentrations in the sediment profiles of limnetic region and in the stand of aquatic macrophytes were compared using factorial analysis of variance (ANOVA factorial; significance level of 0.05).

\section{Results}

Methane production was significantly higher in the macrophytes stand (Table 2, Figure 2 and Figure 3), indicating a positive effect of the detritus of aquatic macrophytes in methanogenesis. In the limnetic region, methane production increased after the $27^{\text {th }}$ day, while in the macrophytes stand the process started after the first day after the sediment incubation. In the beginning of the experiment, methane production in the macrophytes stand was 3 - 7 times higher than in the limnetic region sediment and at the end of the experiment, the methane production became 9 - 57 times higher. Two factors that control methanogenesis were statistically different between the two regions: 1) the significantly highest concentration of DOC and carbohydrates in the macrophytes stand as a whole (Table 2 and Table 3); 2) the significantly highest concentration of $\mathrm{SO}_{4}^{2-}$ in the sediment of the limnetic region as a whole (Table 2 and Table 3 ).

In the sediment profile, the two uppermost sediment layers $(0-2 \mathrm{~cm}$ and $2-6 \mathrm{~cm})$ showed significantly higher methane production than the 6 - $10 \mathrm{~cm}$ profile in the macrophytes stand (Table 4, Figure 2). DOC (Table 3) and carbohydrates (Table 3) concentrations were significantly higher (Table 4) in the uppermost sediment profiles ( 0 - $2 \mathrm{~cm}$ and $2-6 \mathrm{~cm}$ ) and sulfate concentrations (Table 3) were statistically nonsignificant (Table 4) between the sediment profiles of macrophytes stand. DOC concentrations in the uppermost sediment profiles were 2 to 3 times higher than the profile $6-10 \mathrm{~cm}$ and carbohydrate concentrations were 8 to 9 times higher in the macrophytes stand. On the other hand, no significant differences between methane productions in the sediment profiles at the limnetic region were observed (Table 4, Figure 3). In the same way, no differences were observed between the DOC (Table 3 and Table 4), sulfate (Table 3 and Table 4) and carbohydrates concentrations (Table 3 and Table 4) in the sediment profile in this region. 


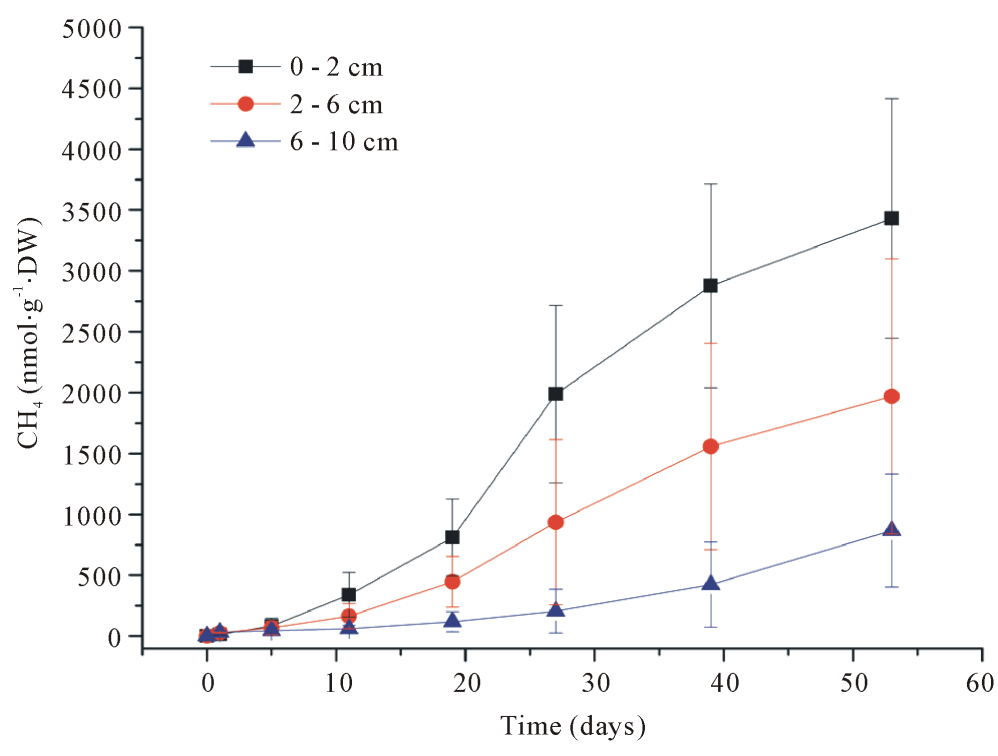

Figure 2. Methane production in the sediment of aquatic macrophytes stand.

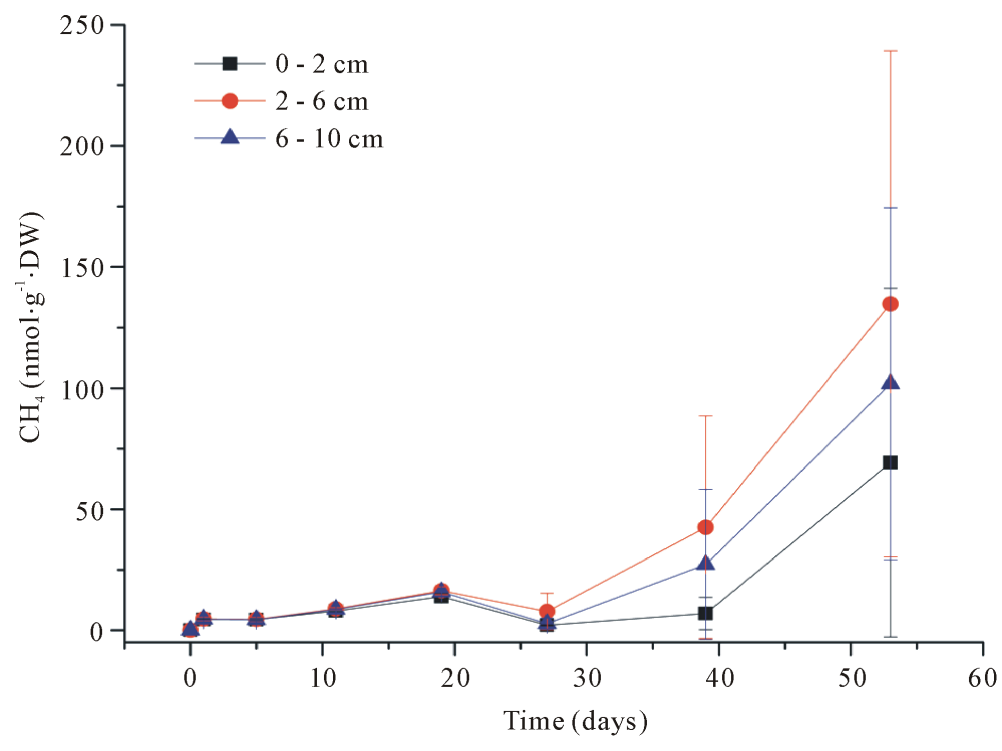

Figure 3. Methane production in the sediment of the limnetic region.

Table 2. Values of significance (p-value) of ANCOVA test, degrees of freedom (df) and values of deviance (F), between methane production in the limnetic region and aquatic macrophytes stand. Values of significance (p-value) of factorial ANOVA test, degrees of freedom (df) and values of deviance (F), between DOC, carbohydrates, $\mathrm{SO}_{4}^{2-}$ and $\mathrm{CH}_{4} \mathrm{Concen}_{-}$ trations in the limnetic region and aquatic macrophytes stand.

\begin{tabular}{ccccc}
\hline Statistical analysis & Variable & df & F-ratio & p-value \\
\hline ANCOVA & $\mathrm{CH}_{4}$ production & 1 & 388.09 & $<0.001^{*}$ \\
Factorial ANOVA & $\mathrm{DOC}$ & 1 & 6.65 & $<0.05^{*}$ \\
Factorial ANOVA & $\mathrm{SO}_{4}^{2-}$ & 1 & 5.69 & $<0.05^{*}$ \\
Factorial ANOVA & Carbohydrates & 1 & 8.81 & $<0.05^{*}$ \\
Factorial ANOVA & $\mathrm{CH}_{4}$ concentration & 1 & 498.88 & $<0.001^{*}$ \\
\hline
\end{tabular}

*Indicates statistical differences. 
Table 3. DOC, carbohydrates, $\mathrm{SO}_{4}^{2-}$ and $\mathrm{CH}_{4}$ concentrations (mean \pm standard deviation (SD)) in the sediment profiles of limnetic region and aquatic macrophytes stand.

\begin{tabular}{lccccc}
\hline \multirow{2}{*}{ Station } & & DOC & Carbohydrates & $\mathrm{SO}_{4}^{2-}$ & $\mathrm{CH}_{4}$ \\
\cline { 3 - 6 } & Layer & $\mu \mathrm{M}$ & $\mu \mathrm{M}$ & $\mu \mathrm{M}$ & $\mu \mathrm{M}$ \\
\cline { 3 - 6 } & & mean $\pm \mathrm{SD}$ & mean $\pm \mathrm{SD}$ & mean $\pm \mathrm{SD}$ & mean $\pm \mathrm{SD}$ \\
\hline \multirow{2}{*}{ Limnetic region } & $2-2$ & $2467.6 \pm 1054.5$ & $488.7 \pm 142.7$ & $1351.3 \pm 477.3$ & n.d. \\
& $2-6$ & $3764.3 \pm 751.3$ & $650.6 \pm 123.7$ & $1206.5 \pm 220.2$ & $0.2 \pm 1.4$ \\
\hline \multirow{2}{*}{ Macrophytes stand } & $6-10$ & $3499.0 \pm 1157.8$ & $460.8 \pm 111.7$ & $1511.9 \pm 402.7$ & $3.7 \pm 3.9$ \\
\hline & $0-2$ & $5149.7 \pm 1626.3$ & $1484.9 \pm 263.5$ & $986.7 \pm 317.6$ & $86.2 \pm 36.7$ \\
& $2-6$ & $7523.4 \pm 1067.1$ & $1521.2 \pm 295.3$ & $1235.2 \pm 298.8$ & $293.6 \pm 69.8$ \\
\end{tabular}

n.d. = not detected.

Table 4. Values of significance (p-value) from Tukey HSD test applied after the ANCOVA analysis for $\mathrm{CH}_{4}$ production and after factorial ANOVA analysis for DOC, carbohydrates, $\mathrm{SO}_{4}^{2-}$ and $\mathrm{CH}_{4}$ concentrations.

\begin{tabular}{|c|c|c|c|c|}
\hline \multirow{2}{*}{ Variable } & \multirow{2}{*}{ Lagoon region } & \multicolumn{3}{|c|}{ Profiles (p-value) } \\
\hline & & $0-2 \mathrm{~cm} \times 2-6 \mathrm{~cm}$ & $0-2 \mathrm{~cm} \times 6-10 \mathrm{~cm}$ & $2-6 \mathrm{~cm} \times 6-10 \mathrm{~cm}$ \\
\hline \multirow{2}{*}{$\mathrm{CH}_{4}$ production } & Limnetic region & 0.600 & 0.910 & 0.993 \\
\hline & Macrophytes stand & 0.679 & $<0.001^{*}$ & $<0.05^{*}$ \\
\hline \multirow{2}{*}{ DOC } & Limnetic region & 0.536 & 0.794 & 0.997 \\
\hline & Macrophytes stand & 0.499 & $<0.05^{*}$ & $<0.05^{*}$ \\
\hline \multirow{2}{*}{ Carbohydrates } & Limnetic region & 0.584 & 1.000 & 0.444 \\
\hline & Macrophytes stand & 1.000 & $<0.001^{*}$ & $<0.001^{*}$ \\
\hline \multirow{2}{*}{$\mathrm{SO}_{4}^{2-}$} & Limnetic region & 0.999 & 0.988 & 0.919 \\
\hline & Macrophytes stand & 0.864 & 0.963 & 0.438 \\
\hline \multirow{2}{*}{$\mathrm{CH}_{4}$ concentration } & Limnetic region & 0.280 & $<0.05^{*}$ & 0.304 \\
\hline & Macrophytes stand & $<0.05^{*}$ & $<0.001^{*}$ & 0.876 \\
\hline
\end{tabular}

*Indicates statistical differences.

As a result of higher production of methane, the methane concentration was significantly higher in the macrophytes stand (Table 2 and Table 3), being 86 - 1615 times higher than in the limnetic region. The methane concentration was significantly higher in the $0-2 \mathrm{~cm}$ profile than in the $6-10 \mathrm{~cm}$ profile in the limnetic region (Table 3 and Table 4). In the macrophytes stand, the methane concentration was significantly higher in the 0 - 2 cm profile in comparison to the profiles 2 - $6 \mathrm{~cm}$ and 6 - $10 \mathrm{~cm}$ (Table 3 and Table 4).

\section{Discussion}

We observed a longitudinal decrease in methane production in the sediment, from the macrophytes stand to the limnetic region and, also a vertical decrease at each site, from the uppermost superficial layer to the deeper one. These results were attributed to the complementary effects of changes in detritus quality and in the availability of sulfate in the sediment. The higher DOC and carbohydrates concentrations and the minor sulfate concentration favored methanogenesis in the sediment of the macrophytes stand. These factors combined act in order to 
reduce competition for substrates between methanogens and sulfate-reducing bacteria in the macrophytes stand and to promote the inhibition of methanogenesis in the limnetic region. Similarly, the decrease in DOC and carbohydrates concentrations in the sediment vertical profile explains the higher methane production in the uppermost layers of the sediment. Our results highlight the benefits of microorganisms in the interaction with aquatic macrophytes, which provide substrates for microbial metabolism and allows the co-occurrence of the processes when there is the availability of common substrates [12] [24].

Reviews of the literature showed that most of the methane produced in the sediment of freshwater ecosystems is derived from recently fixed carbon and methane production decreases when labile substrates are depleted [25]-[27]. In Comprida Lagoon, [28] found that the sources of organic matter in the littoral region is autochthonous (macrophytic) and, in the limnetic region is allochthonous (from the surrounding Restinga), as observed in Cabiunas Lagoon, ecosystems localized in the Restinga de Jurubatiba National Park [29]. The autochthonous organic matter originated from the phytoplanktonic community probably presents a secondary role, since the biomass of phytoplankton is low in Comprida Lagoon [30]. Considering that the organic matter from the surrounding Restinga is primarily recalcitrant [31], the community of aquatic macrophytes is probably the main source of labile organic matter in Comprida Lagoon. It is important to note that the organic matter originated from aquatic macrophytes is derived not only from the plant detritus but also from root exudates. Among the components of root exudates are carbohydrates, which are in part rapidly converted to highly labile organic carbon (e.g. acetate) by microorganisms [27]. Acetate is one of the main methane precursors in freshwater environments [32]. Some studies observed higher rates of acetate formation in the root vicinity, especially during photosynthesis [33] [34]. The stimulus of methane production by the addition of organic carbon from roots in a carbon-accumulating environment may seem paradoxical [34]. However, the detrital organic matter consists mainly of supporting tissues (ca. 73\% for emergent macrophytes) that are refractory to decomposition [35]. In our study, significantly higher carbohydrate concentrations in the stand of aquatic macrophytes indicate the supply of organic carbon to methanogens not only from the dead aquatic macrophytes, but particularly from the interaction among methanogens and live plants through root exudates. The difference in the quantity and quality of carbon is probably one of the factors responsible for the curve shapes of methane production in the two regions, since methane began to accumulate from the beginning of the experiment in the macrophytes stand, indicating that methanogens utilized easily degradable compounds. On the other hand, the sediment from the limnetic region showed a lag phase of 27 days before the start of methane production. This curve shape is probably not only a result of carbon features, but also due to higher sulfate concentration in the limnetic region, which reached values of $1200-1500 \mu \mathrm{M}$. Freshwater ecosystems usually have sulfate concentrations of $100-200 \mu \mathrm{M}$ [5] and, sulfate reducers can out-compete methanogens at freshwater sulfate concentrations of $60-100 \mu \mathrm{M}$, depending on the common substrates availability [36] [37]. Therefore, the production of methane probably began after sulfate depletion.

In the sediment profile, the decrease in quantity and quality of organic carbon may explain the decreasing methane production with depth in the macrophytes stand, especially in the $6-10 \mathrm{~cm}$. Possibly, the fraction is 6 $10 \mathrm{~cm}$ below the root zone, receiving a smaller contribution exudates, but has no limiting conditions for the production of methane, such as nutrient concentrations. Marinho et al. (2010) [29] found that E. interstincta strongly contributed to nutrient enrichment of the sediment of a lagoon nearby the Comprida Lagoon. On the other hand, the carbon probably accumulates in the fraction $6-10 \mathrm{~cm}$ from limnetic region due to nutrient limitation. Furtado et al., (2002) [38] observed low concentrations of soluble reactive phosphorus in the sediment of limnetic region in comparison to the macrophytes stand in Comprida Lagoon. Zink et al. (2004) [28] did not detect total nitrogen in the same region. The availability of sulfate was not a factor responsible for the differences in the methane production in the sediment profile of both regions since there were no significant differences in the sulfate concentrations between the sediment layers.

Methane concentration increased with the sediment depth, as observed in other studies [9] [39] [40]. This pattern is generally observed due to oxidation and methane emissions. Up to 90\% of the methane produced can be oxidized in the first millimeters of the sediment, according to the penetration of oxygen, decreasing the methane concentration in the superficial sediment layer [25] [41] [42]. In Comprida Lagoon, [43] observed an $\mathrm{O}_{2}$ penetration of $3.4 \mathrm{~mm}$ in the sediment, indicating the possibility of methane oxidation. The methane emission occurs through the diffusive flux and by ebullition once the gas reaches supersaturation in the sediment and form bubbles [44]. High contributions of ebullition were observed in shallow environments colonized by aquatic macrophytes [14]-[16], such as Comprida Lagoon. 


\section{Conclusion}

We observe that the presence of aquatic macrophytes benefits the methanogenesis. This interaction occurs not only by providing organic matter from dead plants, but particularly by the release of root exudates from the living plants. The variation in quantity and quality of organic carbon is the main factor that controls the range and shape of the methane production curves. The availability of sulfate presents probably a secondary role, being important when the organic matter is not sufficient for the occurrence of methanogenesis and sulfate reduction simultaneously.

\section{Acknowledgements}

The authors are grateful to CAPES and CNPq for financial support.

\section{References}

[1] Bédard, C. and Knowles, R. (1991) Hypolimnetic $\mathrm{O}_{2}$ Consumtion, Denitrification, and Methanogenesis in a Thermally Stratified Lake. Canadian Journal of Fisheries and Aquatic Sciences, 48, 1048-1054. http://dx.doi.org/10.1139/f91-123

[2] Kuivila, K.M., Murray, J.W., Devol, A.H., Lidstrom, M.E. and Reimers, C.E. (1988) Methane Cycling in the Sediments of Lake Washington. Limnology and Oceanography, 33, 571-581. http://dx.doi.org/10.4319/lo.1988.33.4.0571

[3] Conrad, R. (2007) Microbial Ecology of Methanogens and Methanotrophs. Advances in Agronomy, 96, 1-63. http://dx.doi.org/10.1016/s0065-2113(07)96005-8

[4] McInerney, M.J., Sieber, J.R. and Gunsalus, R.P. (2009) Syntrophy in Anaerobic Global Carbon Cycles. Current Opinion in Biotechnology, 20, 623-632. http://dx.doi.org/10.1016/j.copbio.2009.10.001

[5] Capone, D.G. and Kiene, R.P. (1988) Comparison of Microbial Dynamics in Marine and Freshwater SedimentsContrasts in Anaerobic Carbon Catabolism. Limnology and Oceanography, 33, 725-749. http://dx.doi.org/10.4319/lo.1988.33.4 part 2.0725

[6] Bridgham, S.D., Cadillo-Quiroz, H., Keller, J.K. and Zhuang, Q. (2013) Methane Emissions from Wetlands: Biogeochemical, Microbial, and Modeling Perspectives from Local to Global Scales. Global Change Biology, 19, 1325-1346. http://dx.doi.org/10.1111/gcb.12131

[7] Zak, D., Reuter, H., Augustin, J., Shatwell, T., Barth, M., Gelbrecht, J. and McInnes, R.J. (2015) Changes of the CO and $\mathrm{CH}_{4}$ Production Potential of Rewetted Fens in the Perspective of Temporal Vegetation Shifts. Biogeosciences Discussions, 12, 2455-2468. http://dx.doi.org/10.5194/bg-12-2455-2015

[8] Petruzzella, A., Marinho, C.C., Sanches, L.F., Minello, M. and Esteves, F.A. (2013) Magnitude and Variability of Methane Production and Concentration in Tropical Coastal Lagoons Sediments. Acta Limnologica Brasiliensia, 25, 341351. http://dx.doi.org/10.1590/S2179-975X2013000300012

[9] Fonseca, A.L.S., Minello, M., Marinho, C.C. and Esteves, F.A. (2004) Methane Concentration in Water Column and in Pore Water of a Coastal Lagoon (Cabiúnas Lagoon, Macaé, RJ, Brazil). Brazilian Archives of Biology and Technology, 47, 301-308. http://dx.doi.org/10.1590/S1516-89132004000200018

[10] Esteves, F.A. (2011) Fundamentos de Limnologia. 3rd Edition, Interciência, Rio de Janeiro.

[11] Lyimo, T.J., Pol, A. and Den-Camp, H.J.M.O. (2002) Sulfate Reduction and Methanogenesis in Sediments of Mtoni Mangrove Forest, Tanzania. AMBIO, 31, 614-616.

[12] Ward, D.M. and Winfrey, M.R. (1985) Interactions between Methanogenic and Sulfate-Reducing Bacteria in Sediments. In: Jannasch, H.W. and Williams, P.J.L., Eds., Advances in Microbial Ecology, Plenum Press, New York, 219286.

[13] Bousquet, P., Ciais, P., Miller, J.B., Dlugokencky, E.J. Hauglustaine, D.A., Prigent, C., Van der Werf, G.R., Peylin, P., Brunke, E.-G., Carouge, C., Langenfelds, R.L., Lathière, J., Papa, F., Ramonet, M., Schmidt, M., Steele, L.P., Tyler, S.C. and White, J. (2006) Contribution of Anthropogenic and Natural Sources to Atmospheric Methane Variability. Nature, 443, 439-443. http://dx.doi.org/10.1038/nature05132

[14] Bastviken, D., Santoro, A.L., Marotta, H., Pinho, Q.L., Calheiros, D.F., Crill, P. and Enrich-Prast, A. (2010) Methane Emissions from Pantanal, South America, during the Low Water Season: Toward More Comprehensive Sampling. Environmental Science \& Technology, 44, 5450-5455. http://dx.doi.org/10.1021/es1005048

[15] Marinho, C.C., Palma-Silva, C., Albertoni, E.F., Giacomini, I.B., Barros, M.P.F., Furlanetto, L.M. and Esteves, F.A. (2015) Emergent Macrophytes Alter the Sedimentcomposition in a Small, Shallow Subtropical Lake: Implications for Methane Emission. American Journal of Plant Science, 6, 315-322. http://dx.doi.org/10.4236/ajps.2015.62036

[16] Peixoto, R.B., Machado-Silva, F., Marotta, H., Enrich-Prast, A. and Bastviken, D. (2015) Spatial versus Day-to-Day Within-Lake Variability in Tropical Floodplain Lake $\mathrm{CH}_{4}$ Emissions-Developing Optimized Approaches to Repre- 
sentative Flux Measurements. PLoS ONE, 10, e0123319. http://dx.doi.org/10.1371/journal.pone.0123319

[17] Forster, P., Ramaswamy, V., Artaxo, P., Berntsen, T., Betts, R., Fahey, D.W., Haywood, J., Lean, J., Lowe, D.C., Myhre, G., Nganga, J., Prinn, R., Raga, G., Schulz, M. and Van Dorland, R. (2007) Changes in Atmospheric Constituents and in Radiative Forcing. In: Solomon, S., Qin, D., Manning, M., Chen, Z., Marquis, M., Averyt, K.B., Tignor, M. and Miller, H.L., Eds., Climate Change 2007: The Physical Science Basis, Contribution of Working Group I to the 4th Assessment Report of the Intergovernmental Panel on Climate Change, Cambridge University Press, Cambridge, 129234.

[18] FIDERJ (1977) Estudos para o planejamento municipal. Rio de Janeiro, Macaé.

[19] Panosso, R.F., Attayde, J.L. and Muehe, D. (1998) Morfometria das lagoas Imboassica, Cabiúnas, Comprida e Carapebus: Implicações para seu funcionamento e manejo. In: Esteves, F.A., Ed., Ecologia das Lagoas Costeiras do Parque Nacional da Restinga de Jurubatiba e do Município de Macaé (RJ), NUPEM/UFRJ, Rio de Janeiro, 91-105.

[20] Ambühl, H. and Bührer, H. (1975) Zur Technik der Entnahme ungestörter Großproben von Seesedimenten: Ein verbessertes Bohrlot. Schweizerische Zeitschrift für Hydrologie, 37, 175-186.

[21] Casper, P. (1992) Methane Production in Lakes of Different Trophic State. Archiv für Hydrobiologie Beiheft Ergebnisse Limnologie, 37, 149-154.

[22] Golterman, H.L., Clymo, R.S. and Ohnstad, M.A.M. (1978) Methods of Physical and Chemical Analysis of Freshwaters. Blackwell, Oxford.

[23] American Public Health Association-APHA (1998) Standard Methods for the Examination of Water and Wastewater. 20th Edition, APHA, Washington DC.

[24] Estop-Aragonés, C., Knorr, K.-H. and Blodau, C. (2013) Belowground in Situ Redox Dynamics and Methanogenesis Recovery in a Degraded Fen during Dry-Wet Cycles and Flooding. Biogeosciences, 10, 421-436. http://dx.doi.org/10.5194/bg-10-421-2013

[25] Segers, R. (1998) Methane Production and Methane Consumption: A Review of Processes Underlying Wetland Methane Fluxes. Biogeochemistry, 41, 23-51. http://dx.doi.org/10.1023/A:1005929032764

[26] Whalen, S.C. (2005) Biogeochemistry of Methane Exchange between Natural Wetlands and the Atmosphere. Environmental Engineering Science, 22, 73-94. http://dx.doi.org/10.1089/ees.2005.22.73

[27] Laanbroek, H.J. (2013) Methane Emission from Natural Wetlands: Interplay between Emergent Macrophytes and Soil Microbial Processes. A Mini-Review. Annals of Botany, 105, 141-153. http://dx.doi.org/10.1093/aob/mcp201

[28] Zink, K.-G., Furtado, A.L.S., Casper, P. and Schwark, L. (2004) Organic Matter Composition in the Sediment of Three Brazilian Coastal Lagoons District of Macaé, Rio de Janeiro (Brazil). Anais da Academia Brasileira de Ciências, 76, 29-47. http://dx.doi.org/10.1590/S0001-37652004000100004

[29] Marinho, C.C., Meirelles-Pereira, F., Gripp, A.R., Guimaraes, C.C., Esteves, F.A. and Bozelli, R.L. (2010) Aquatic Macrophytes Drive Sediment Stoichiometry and the Suspended Particulate Organic Carbon Composition of a Tropical Coastal Lagoon. Acta Limnologica Brasiliensia, 22, 208-217. http://dx.doi.org/10.1590/S2179-975X2010000200010

[30] Alves-de-Souza, C., Menezes, M. and Huszar, V. (2006) Phytoplankton Composition and Functional Groups in a Tropical Humic Coastal Lagoon, Brazil. Acta Botanica Brasilica, 20, 701-708. http://dx.doi.org/10.1590/S0102-33062006000300019

[31] Farjalla, V.F., Marinho, C.C. and Esteves, F.A. (1999) Uptake of Oxygen in the Initial Stages of Decomposition of Aquatic Macrophytes and Detritus from Terrestrial Vegetation in a Tropical Coastal Lagoon. Acta Limnologica Brasiliensia, 11, 185-193.

[32] Whiticar, M.J., Faber, E. and Schoell, M. (1986) Biogenic Methane Formation in Marine and Freshwater Environments: $\mathrm{CO}_{2}$ Reduction vs. Acetate Fermentation-Isotope Evidence. Geochimica et Cosmochimica Acta, 50, 693-709. http://dx.doi.org/10.1016/0016-7037(86)90346-7

[33] Conrad, R. and Klose, M. (1999) Anaerobic Conversion of Carbon Dioxide to Methane, Acetate and Propionate on Washed Rice Roots. FEMS Microbiology Ecology, 30, 147-155. http://dx.doi.org/10.1111/j.1574-6941.1999.tb00643.x

[34] Ström, L., Ekberg, A., Mastepanov, M. and Christensen, T.O. (2003) The Effect of Vascular Plants on Carbon Turnover and Methane Emissions from a Tundra Wetland. Global Change Biology, 9, 1185-1192. http://dx.doi.org/10.1046/j.1365-2486.2003.00655.x

[35] Bianchini Jr., I. and Cunha-Santino, M.B. (2008) As rotas de liberação do carbono dos detritos de macrófitas aquáticas. Oecologia Brasiliensis, 12, 20-29. http://dx.doi.org/10.4257/oeco.2008.1201.03

[36] Lovley, D.R., Dwyer, D.F. and Klug, M.J. (1982) Kinetic Analysis of Competition between Sulfate Reducers and Methanogens in Sediments. Applied and Environmental Microbiology, 43, 1373-1379.

[37] Lovley, D.R. and Klug, M.J. (1983) Sulfate Reducers Can Outcompete Methanogens at Freshwater Sulfate Concentrations. Applied and Environmental Microbiology, 45, 187-192. 
[38] Furtado, A.L.S., Casper, P. and Esteves, F.A. (2002) Methanogenesis in an Impacted and Two Dystrophic Coastal Lagoons (Macaé, Brazil). Brazilian Archives of Biology and Technology, 45, 195-202. http://dx.doi.org/10.1590/S1516-89132002000200011

[39] Benstead, J. and Lloyd, D. (1996) Spatial and Temporal Variations of Dissolved Gases $\left(\mathrm{CH}_{4}, \mathrm{CO}_{2}\right.$, and $\left.\mathrm{O}_{2}\right)$ in $\mathrm{Peat}$ Cores. Microbial Ecology, 31, 57-66. http://dx.doi.org/10.1007/BF00175075

[40] van der Nat, F.-J. and Middelburg, J.J. (2000) Methane Emission from Tidal Freshwater Marshes. Biogeochemistry, 49, 103-121. http://dx.doi.org/10.1023/A:1006333225100

[41] Frenzel, P., Thebrath, B. and Conrad, R. (1990) Oxidation of Methane in the Oxic Surface Layer of a Deep Lake Sediment (Lake Constance). FEMS Microbiology Letters, 73, 149-158. http://dx.doi.org/10.1111/j.1574-6968.1990.tb03935.x

[42] King, G.M., Roslev, P. and Skovgaard, H. (1990) Distribution and Rate of Methane Oxidation in Sediments of the Florida Everglades. Applied and Environmental Microbiology, 56, 2902-2911.

[43] Nielsen, L.P., Enrich-Prast, A. and Esteves, F.A. (2004) Pathways of Organic Matter Mineralization and Nitrogen Regeneration in the Sediment of Five Tropical Lakes. Acta Limnologica Brasiliensia, 16, 193-202.

[44] Bartlett, K.B. and Harriss, R.C. (1993) Review and Assessment of Methane Emissions from Wetlands. Chemosphere, 26, 261-320. http://dx.doi.org/10.1016/0045-6535(93)90427-7 